\title{
Optical LAN Card for a Laptop PC
}

\author{
Seiji Fukushima Non-member (NTT Photonics Laboratories, fksm@aecl.ntt.co.jp) \\ Naoto Sugimoto Non-member (NTT Electronics, sugimoto@atsu1.nel.co.jp) \\ Yuji Akatsu Non-member (NTT Photonics Laboratories, akatsu@aecl.ntt.co.jp) \\ Yoshihisa Sakai Non-member (NTT Photonics Laboratories, sacay@aecl.ntt.co.jp) \\ Kimio Oguchi Member (Seikei University, oguchi@st.seikei.ac.jp)
}

Keywords : laptop PC, optical local area network, hybrid optical circuit, wavelength division multiplexing

Toward realization of photonic home network or fiber-to-thedesktop (FTTD) network, we have developed optical LAN interface cards for a laptop computer. Optical network has been applied to high-bit-rate communication network, and the merit of high bit rate remains the same even in the home network. We show, in this paper, that a-few-hundred-Mbit/s communication is achieved by using our LAN cards.

We developed two kinds of LAN cards; one for 100BASE-FX and another 1000BASE-LX protocol. The two cards are called a $100 \mathrm{M}$-card and a 1G-card in this summary. The 100M-card consists of a planer-light-circuit optical transceiver and some electronic interface circuits, equipped with a MU optical connector and a PCMCIA electric connector. The 100M-card is thin and small, as shown in Fig. 1. Its volume and weight is $37 \mathrm{ml}$ and $53 \mathrm{~g}$, respectively. Although the communication distance of unshielded-twisted-pair cable 100-Mbit/s Ethernet is limited to about $150 \mathrm{~m}$, the distance of optical Ethernet was measured as 30

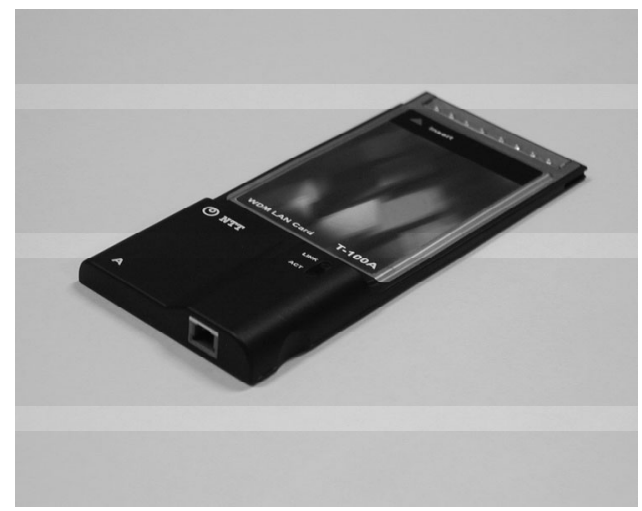

Fig. 1. Photograph of the 100M-card $\mathrm{km}$. The power consumption is only $2 \mathrm{~W}$, which can be taken from a PCMCIA bus.

The light wavelengths are $1.3 \mu \mathrm{m}$ and $1.55 \mu \mathrm{m}$ for an up stream and a down stream, both of which are wavelength division multiplexed (WDM). Due to the WDM employment in a single-mode fiber, users can connect the LAN cards easily.

The 1G-card is larger than the 100M-card since some devices are larger. For example, the employed optical transceiver is a small-form-factor pluggable module, which is much larger than the integrated planar light circuit. The volume and weight of the $1 \mathrm{G}$-card is $112 \mathrm{ml}$ and $99 \mathrm{~g}$, respectively.

The maximum communication distance was measured as 60 $\mathrm{km}$; however, the throughput was $200 \mathrm{Mbit} / \mathrm{s}$ even though we used the 1000BASE-specification devices. A primary reason of slowing down seems an insufficient performance of a PCMCIA driver in our laptop computer in the experimental setup. Table 1 shows characteristics of our LAN cards and commercial interfaces. As can be seen, our LAN card is compatible with the CardBus and consumes less power. Hence, these interface cards will play a great roll in the home network.

Table 1. Characterisitics of the network interfaces

\begin{tabular}{|c|c|c|c|}
\hline & $\begin{array}{c}\text { Developed 1-Gb/s } \\
\text { optical LAN card }\end{array}$ & $\begin{array}{c}\text { Developed 100M } \\
\text { LAN card }\end{array}$ & $\begin{array}{c}\text { NIC for optical } \\
\text { Ethernet }\end{array}$ \\
\hline Bus interface & CardBus & CardBus & PCI \\
\hline Optical interface & SC simplex & MU simplex & SC duplex \\
\hline $\begin{array}{c}\text { Size } \\
(\mathbf{L} \times \mathbf{W} \times \mathbf{H}, \mathrm{mm})\end{array}$ & $\begin{array}{c}\mathbf{1 5 9 . 0 \times 5 7 . 0 \times} \\
\mathbf{1 0 . 5}\end{array}$ & $\begin{array}{c}\mathbf{1 3 0 . 6} \times \mathbf{5 4 . 0} \times \\
\mathbf{4 . 2}\end{array}$ & $\begin{array}{c}\sim \mathbf{1 3 0 \times \sim 8 0 \times} \\
\sim 19\end{array}$ \\
\hline Maximum power (W) & 3 & 2 & $5-14$ \\
\hline Throughput (Mb/s) & 200 & 95 & $\sim 500$ \\
\hline $\begin{array}{c}\text { Communication } \\
\text { distance }(\mathbf{k m})\end{array}$ & $\sim 60$ & $\sim 30$ & $0.5-60$ \\
\hline
\end{tabular}




\section{ノート PC 用光 LAN カード}

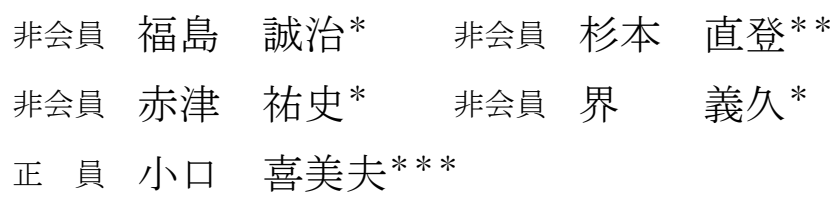

\section{Optical LAN Card for a Laptop PC}

Seiji Fukushima*, Non-member, Naoto Sugimoto**, Non-member, Yuji Akatsu*, Non-member, Yoshihisa Sakai*, Non-member, Kimio Oguchi***, Member

Toward the realization of fiber-to-the-desktop network, we have developed optical LAN card interfaces that are compatible with a PCMCIA interface of laptop PCs. This paper reports the structures and characteristics of the interfaces. Some applications are discussed, including office and home network.

キーワード : ノート PC, 光 LAN, ハイブリッド光回路, 波長分割多重

Keywords : laptop PC, optical local area network, hybrid optical circuit, wavelength division multiplexing

\section{1. 序 論}

FTTH の進展に加え, オフィスや家庭内のような短距離 ネットワークの進展は著しい。とりわけ，動画像のような 容量の大きなデータのやりとりが可能になり，さらなる大 容量化も期待されている。IP 系の LAN においては, 100BASE-TX から 1000BASE-T へと進化してきた。 $100 \mathrm{Mb} / \mathrm{s}$ から $1 \mathrm{~Gb} / \mathrm{s}$ ヘとデータレートは向上しているもの の，一般にはUTP (unshielded twisted pair)ケーブルを用 いた LAN が標準的である。メタル系の配線においては，接 続距離, 電磁界漏洩, 敷設が課題となる。また, $10 \mathrm{~Gb} / \mathrm{s}$ 一 の高速化においては，接続距離の問題はさらに顕著になる。 一般にメタル系が $100 \mathrm{~m}$ 程度の接続距離であるのに対して, 長波長光ファイバでは 1000BASE-LX で $5 \mathrm{~km}$ (波長 1310nm)，10GBASE-ER で 40km(波長 1550nm)の接続距 離が実現できる(1)。

また，光イーサネットはアクセス系にも適用されている (2)。現段階の家庭における光化は $\mathrm{OE}$ 変換を担う ONU やメ ディアコンバータ $(\mathrm{MC})$ までとなっているが, 近い将来光イ

* 日本電信電話株式会社 NTTフォトニクス研究所 平 $243-0198$ 神奈川県厚木市森の里 3-1

NTT Photonics Laboratories, NTT Corporation 3-1 Morinosato Wakamiya, Atsugi, Kanagawa 243-0198

** NTT エレクトロニクス株式会社

于194-0004 東京都町田市鶴間 1841-1

NTT Electronics Corporation

1841-1 Tsuruma, Machida, Tokyo 194-0004

*** 成蹊大学 理工学部

=180-8633 東京都武蔵野市吉祥寺 3-3-1

Faculty of Science and Engineering, Seikei University

3-3-1 Kichijouji, Musashino, Tokyo 180-8633
ンタフェースを搭載した PC が実現され, 光化はラスト $1 \mathrm{~cm}$ まで実現可能であると考えられる。この状態を，FTTD (fiber-to-the-desktop) と呼ぶ。我われはノート PC に標準的 に装備された PCMCIA インタフェース互換のノート PC 用 光 LAN カードの研究開発を進めてきた。現在ギガビットイ 一サ対応カードまで実現している。本論文ではこれらの光 LAN カードの構造, 性能, 応用を報告する。

\section{FTTD インタフェース}

現在のところ，イーサネット接続の規格'NIC' (network interface card）としてはメタル系の 1000BASE-T と 100BASE-TX が主に使用されている。また, PC 側では PCI やCardBus インタフェースが広く採用されている。一部で 使用されている NIC の光規格 1000BASE-SX では, PCI カ ードと SC コネクタがそれぞれ PC 側とネットワーク側のイ ンタフェースとして採用されている。LAN の光化を展望し た場合, 1000BASE-SX では小型化などが FTTD 汎用化の 障害となりうる。デスクトップにおいてもノート型 PC を採 用した場合, インタフェースは PCにふさわしい小型で低消 費電力のものが望まれる。ノート PC では PCI バスでなく PCMCIA が標準的であり, PCMCIA から取得可能な電力は $2 \mathrm{~W}$ であるため, 相灾の低電力化も必要である。汎用化にあ たっては低コストであることも重要であるが, 現在の光フ アイバインタフェースの NIC はメタル系 NIC より 10 倍程 度高価である。

また, 現存の光系 NIC ではアップ／ダウンリンクに 2 心 の光ファイバが使用されている。 NIC に波長分割多重 
(WDM)を導入すれば，ファイバがさらに有効に使用され， 光ファイバの扱いに慣れないユーザによる接続もより容易 になる。FTTH のようなアクセス系ですでに広くWDM は 採用されており，小型化の問題を克服すれば FTTD におい ても WDM 化によるメリットは多い。

光 LAN カードの特徵から考えられる応用領域について 述べる。FTTD を実現した場合には，LAN の高スループッ ト化によって動画などのより多彩なアプリケーションやコ ンテンツが実現できる。この恩恵の影響はオフィス LAN だ けでなくホームネットワークやアクセス系ネットワークも 同様である。とりわけ高画質の動画を扱う場合には，大き なスループットが要求される。メタルに対する光ファイバ の優位性として, 高スループットや低損失の他に低電磁誘 導が挙げられる。この特徵は高雑音環境である工場のネッ トワーク化で有効となる。すなわち, 比較的大きな雑音を 発生する機器とその制御系を光ファイバにより分離するこ とで, 電磁誘導を最小限にすることができる。低電磁誘導 は病院のネットワーク化でも有効であると考えられる。こ の場合は, PC やネットワーク機器と微弱信号を扱う医療機 器とを電気的に分離することで, 電磁誘導を抑えることが 可能になる。

\section{3. $100 \mathrm{Mb} / \mathrm{s}$ 光 LAN カード}

本研究開発の第 1 歩として, $100 \mathrm{Mb} / \mathrm{s}$ 光 LAN カードの試 作を行った。PC 側のインタフェースは PCMCIA (Type II) で，ネットワーク側のインタフェースは MU コネクタ経由 の 1 心 SMF (single mode fiber)である。1 心インタフェー スの実現のために, ネットワークから PCへのダウンリンク に $1.55 \mu \mathrm{m}$ 帯, PC からネットワークへのアップリンクに $1.3 \mu \mathrm{m}$ の波長帯の WDM を用いた。ただし, 製作した光 LAN カードの測定のために対向して使用できる光 LAN カ ードも試作した。この光 LAN カードでは, ダウンリンクが $1.3 \mu \mathrm{m}$ 帯でアップリンクが $1.55 \mu \mathrm{m}$ 帯となる。WDM シス テムでは，このように 2 種の波長構成が必要となるが，構 成部品のうち取り替える必要があるものは LD のみである ため, WDM のために開発コストが著しく大きくなることは ない。

光 LAN カードの中には, 光トランシーバ(TRX)モジュー ル, 光コネクタ, 電子部品(100BASE-FX MAC チップ, PHY チップ), PCMCIA コネクタを実装した。図 1 に $100 \mathrm{Mb} / \mathrm{s}$ 光 LAN カードの構造と寸法を, 図 2 にその写真を 示す。用いた光部品について説明する。Type-II PCMCIA を実装するために，光コネクタとして MU 型(3)を用いた。 $\mathrm{MU}$ コネクタは基本的な仕様が $\mathrm{SC}$ コネクタと同様である が, コネクタ体積が SC の $1 / 4$ と小型であり, 光 LAN カー ドの小型化へのキーテクノロジーのひとつであった。さて, 光 TRX モジュールとしては LD, 導波型 PD(WG-PD), モ ニタ $\mathrm{PD}$, 波長分割多重(WDM)フィルタをハイブリッド集 積した PLC 回路を用いた。これらの部品の使用によって, 重量 $53 \mathrm{~g}$ でノート PC に収まる光 LAN カードを実現した。
低コスト化可能な部品のみで構成したため, ノート型 PC の オプションとしても将来の価格は現実的なものになると考 えられる。

表 1 に試作した光 LAN カードと市販された NIC の性能 比較を記す。本光 $\mathrm{LAN}$ カードの寸法は $130.6 \times 54.0 \times 4.2$ $\mathrm{mm}$ (最厚部は $9.7 \mathrm{~mm}$ )で, 小型である。体積は $37 \mathrm{ml}$ で,

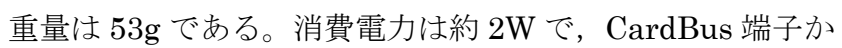
ら取得可能な電力である。電力の大部分は光部品でなく,

MAC チップや PHY チップなどの電気系インタフェースで 消費されている。

図 3 はスループットのファイバ長依存性の測定系で, 図 4 はその測定結果である。スループットは $1 \mathrm{MB}$ のファイルを FTP 転送する時間測定によって計測した。ここでスループ ットとは, IP 層のスループットである。PC の CPU は 2 台

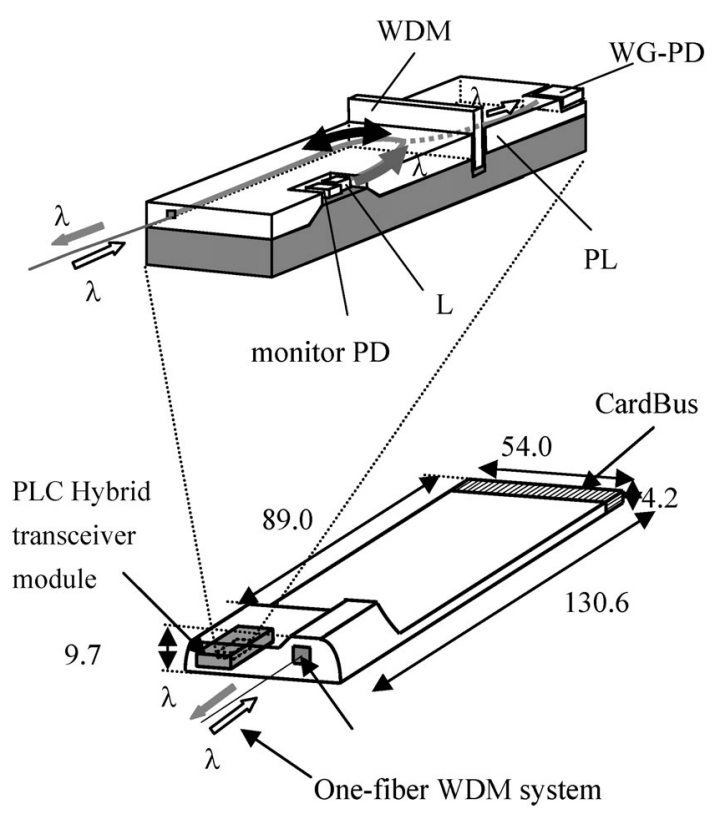

図 $1100 \mathrm{Mb} / \mathrm{s}$ 光 $\mathrm{LAN}$ カードの構造と寸法 $(\mathrm{mm})$

Fig. 1. Structure and dimensions (in $\mathrm{mm}$ ) of the developed 100-Mb/s optical LAN card

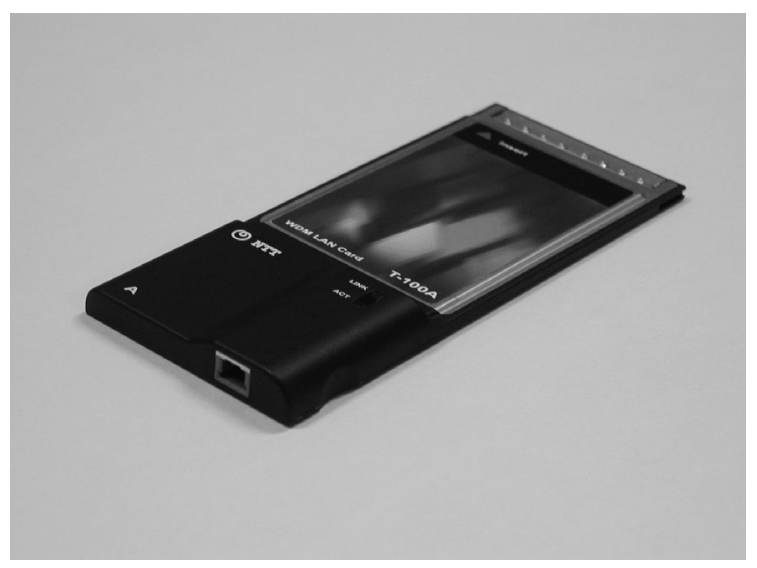

図 $2100 \mathrm{Mb} / \mathrm{s}$ 光 $\mathrm{LAN}$ カードの写真

Fig. 2. Photograph of 100-Mb/s optical LAN card 
とも Pentium 4 である。図 4 では, 光 LAN カードの結果 と 100BASE-TXのメタル系インタフェースの結果を比較し た。150m 以下の短い距離においては，いずれのインタフェ 一スも 85-95Mb/s 級のスループットが実現される。メタル 系がわずか $150 \mathrm{~m}$ でスループット急落するのに対して，光 LAN カードでは $30 \mathrm{~km}$ までほぼ一定のスループットを示し た。なお，スループット急落の原因は，光ファイバにおい ては光ファイバの損失に起因する感度不足であり, メタル

\section{表 $1100 \mathrm{Mb} / \mathrm{s}$ NIC $の$ 性能}

Table 1. Characteristics of $100-\mathrm{Mb} / \mathrm{s}$ NICs

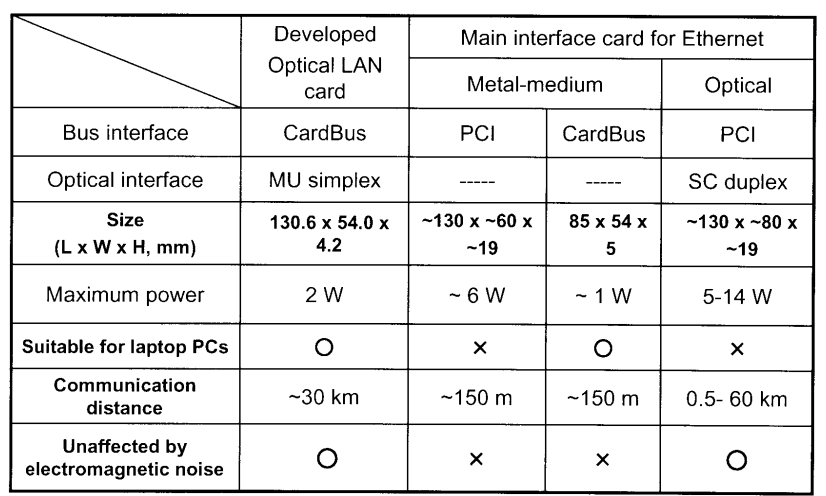

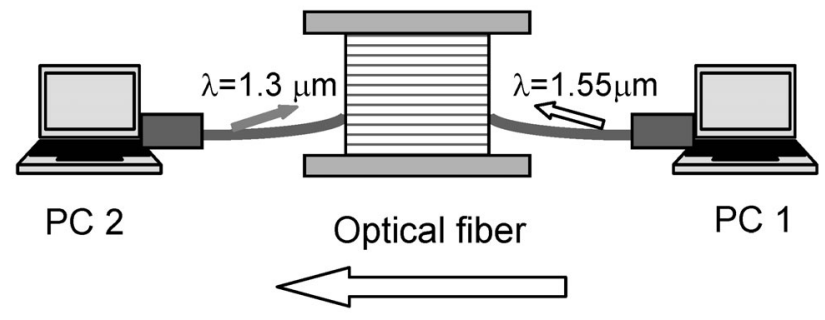

図 3 光 LAN カードのスループット測定系

Fig. 3. Measurement setup of optical LAN cards

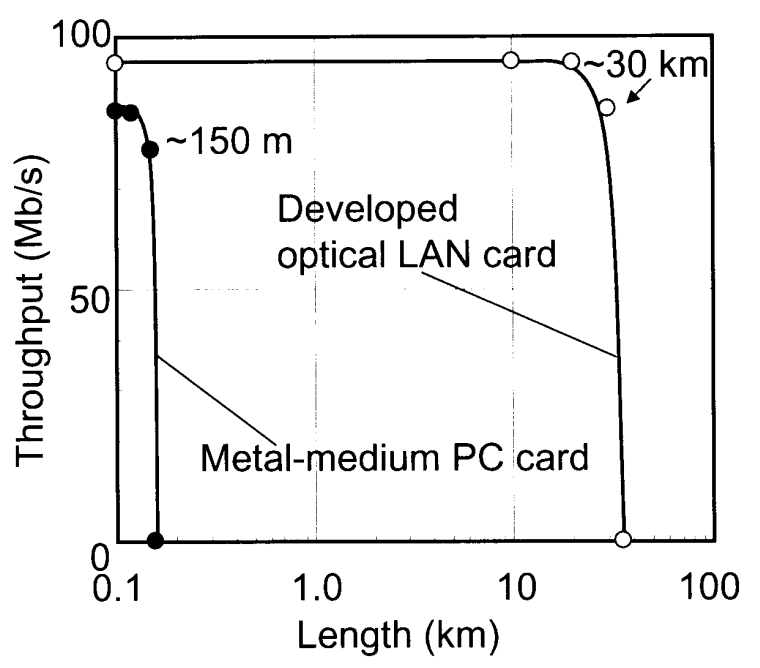

図 $4100 \mathrm{Mb} / \mathrm{s}$ 光 LAN カードスループットの

$$
\text { ファイバ長依存性 }
$$

Fig. 4. Dependency of $100-\mathrm{Mb} / \mathrm{s}$ optical LAN card throuput on optical fiber length
系においては媒体の大域不足であると考えられる。直結時 の光 LANカードとメタル系インタフェースのスループット の差は本質的なものではなく, それぞれで使用されたイン タフェース IC の性能差によるものと考えられる。

\section{4. $1 \mathrm{~Gb} / \mathrm{s}$ 光 $\mathrm{LAN}$ カード}

第 2 ステップとしてギガビットイーサ用 $1 \mathrm{~Gb} / \mathrm{s}$ 光 $\mathrm{LAN}$ カ ードの試作を行った。図 5 は, この光 LAN カードの構造で ある。WDM 化した 1 心ファイバであることは前章の結果 と同じであるが，寸法が大型である。PCMCIA の Type-II 規格にすべての部品を実装できなかったため, Type-III 規 格である。ネットワーク側の規格は 1000BASE-LX であり， コネクタは $\mathrm{SC}$ 型である。光 $\mathrm{TRX}$ としては, $1.3 / 1.49 \mu \mathrm{m}$ 帯 WDM 一心型 SFP (small form-factor pluggable) 光 TRX を用いた。なお, SFP は光 TRX モジュールの標準規格のひ とつである。製作した光 LAN カードの最小受信感度は $-24 \mathrm{dBm}$, 最大受信感度は- $3 \mathrm{dBm}$ であった。また, $\mathrm{SC} コ ネ$ クタ端で測定された LD の出力光強度は- $6 \mathrm{dBm}$ である。

本光 LAN カードのスループットの測定結果を図 6 に示 す。前章と同様に $1 \mathrm{MB}$ のファイル転送(FTP)により, 測定 を行った。本光カードではファイバ長 $100 \mathrm{~m}$ において $200 \mathrm{Mb} / \mathrm{s}$ のスループットを示し, 距離が延びるにともない スループットは低下した。最大伝送距離は約 $60 \mathrm{~km}$ であっ たが，この距離は光ファイバの損失や光 TRX の性能から見 積もられる計算值とおよそ一致する。しかし，スループッ トの光ファイバ長依存性曲線は $100 \mathrm{Mb} / \mathrm{s}$ 光 $\mathrm{LAN}$ カードの 結果とは異なり, 光ファイバ長の増加につれて少しずつ低 下する。この原因は検討中であり，今後改善をはかりたい。 $1 \mathrm{~Gb} / \mathrm{s}$ 光 $\mathrm{LAN}$ カードの光 TRX 性能は, $100 \mathrm{Mb} / \mathrm{s}$ 光 $\mathrm{LAN}$ カードのそれより優れているため, ビットレートがより大 きことにかかわらず, より長距離の光ファイバ伝送が可能 であった。

また, 最大スループットは光 TRX モジュールの性能にか かわらず，使用したノート PC の CardBus ドライバによっ て律速された。実験における最大スループットは約 $200 \mathrm{Mb} / \mathrm{s}$ であった。ノート PC で標準的に装備されたイン

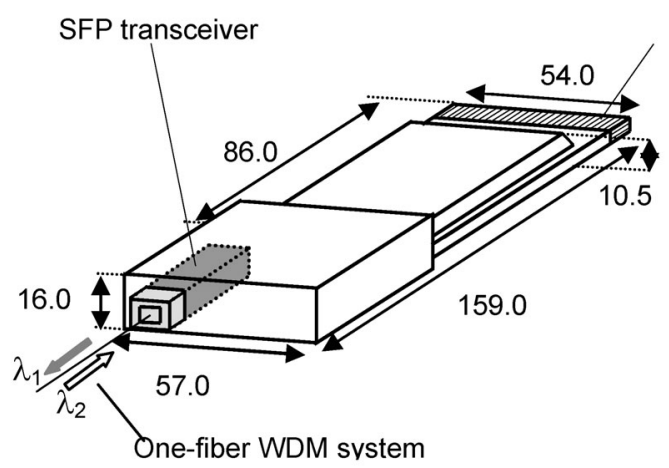

図 $51 \mathrm{~Gb} / \mathrm{s}$ 光 LAN カードの構造と寸法 $(\mathrm{mm})$

Fig. 5. Structure and dimensions (in $\mathrm{mm}$ ) of the developed 1-Gb/s optical LAN card 


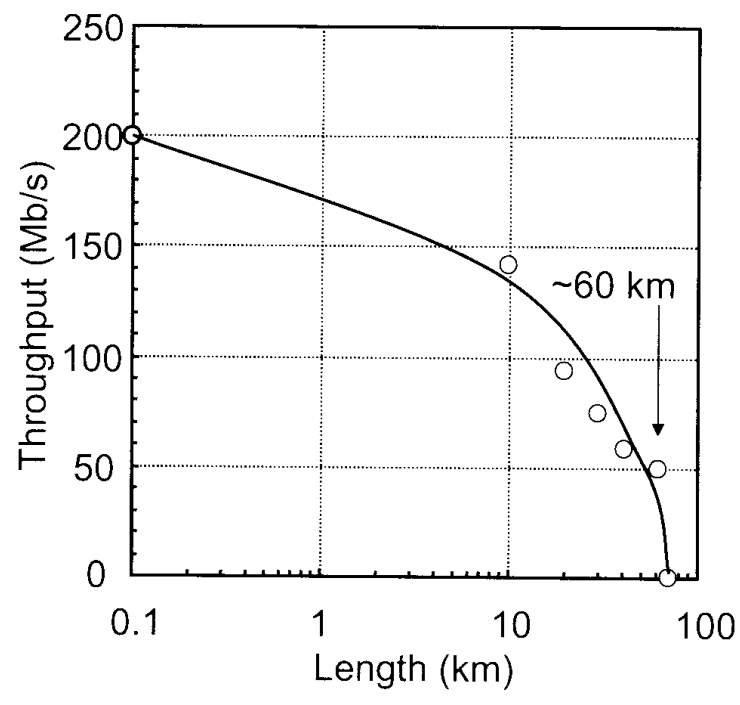

図 $61 \mathrm{~Gb} / \mathrm{s}$ 光 $\mathrm{LAN}$ カードスループットのファイ バ長依存性

Fig. 6. Dependency of $1-\mathrm{Gb} / \mathrm{s}$ optical LAN card throughput on optical fiber length

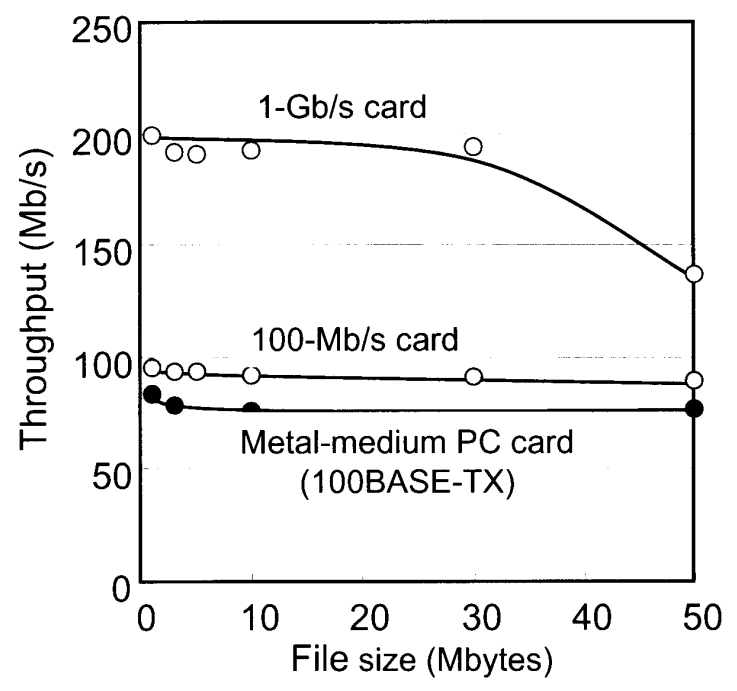

図 7 スループットのファイル容量依存性

Fig. 7. Throughput dependency on the file size

表 $21 \mathrm{~Gb} / \mathrm{s}$ NIC の性能

Table 2. Characteristics of 1-Gb/s NICs

\begin{tabular}{|c|c|c|c|}
\hline & $\begin{array}{c}\text { Developed 1-Gb/s } \\
\text { optical LAN card }\end{array}$ & $\begin{array}{c}\text { Developed 100M } \\
\text { LAN card }\end{array}$ & $\begin{array}{c}\text { NIC for optical } \\
\text { Ethernet }\end{array}$ \\
\hline Bus interface & CardBus & CardBus & $\mathrm{PCI}$ \\
\hline Optical interface & SC simplex & MU simplex & SC duplex \\
\hline $\begin{array}{c}\text { Size } \\
(\mathbf{L} \times \mathbf{~ W ~} \mathbf{~ H , ~} \mathbf{m m})\end{array}$ & $\begin{array}{c}\mathbf{1 5 9 . 0 \times 5 7 . 0 \times} \\
\mathbf{1 0 . 5}\end{array}$ & $\begin{array}{c}130.6 \times 54.0 \times \\
\mathbf{4 . 2}\end{array}$ & $\begin{array}{c}\sim 130 \times \sim 80 \times \\
\sim 19\end{array}$ \\
\hline Maximum power $(\mathrm{W})$ & 3 & 2 & $5-14$ \\
\hline \begin{tabular}{c} 
Throughput $(\mathrm{Mb} / \mathrm{s})$ \\
\hline $\begin{array}{c}\text { Communication } \\
\text { distance }(\mathbf{k m})\end{array}$
\end{tabular} & 200 & 95 & $\sim 500$ \\
\hline
\end{tabular}

タフェースを前提とする場合, USB 2.0 端子を用いれば $480 \mathrm{Mb} / \mathrm{s}$ のスループットが実現されると考えられる。

上記の実験では転送されるファイルの容量を $1 \mathrm{MB}$ 一定 で行ったが, 次にファイル容量依存性を調べた。ファイバ 長は $2 \mathrm{~m}$ で, 使用した PC は他の実験と同じある。図 7 に示 されるようにメタル系の 100BASE-TX の NIC と 100Mb/s 光 LANカードにおいては, ファイル容量を $1 \mathrm{MB}$ から $50 \mathrm{MB}$ の間で変化させてもスループットの変動はほとんど観測さ れなかった。100BASE-TX の NIC の場合は約 $85 \mathrm{Mb} / \mathrm{s}$ 一 定で, $100 \mathrm{Mb} / \mathrm{s}$ 光 LAN カードの場合は約 $95 \mathrm{Mb} / \mathrm{s}$ であった。 一方, $1 \mathrm{~Gb} / \mathrm{s}$ 光 LAN カードでは, ファイル容量 $1 \mathrm{MB}$ から $30 \mathrm{MB}$ の間ではスループットが約 $200 \mathrm{Mb} / \mathrm{s}$ 一定で, ファイ ル容量が $50 \mathrm{MB}$ ではスループット約 $140 \mathrm{Mb} / \mathrm{s}$ まで低下し た。このスループット低下は PC 内のハードディスクアクセ スに基づくものであると考えられる。

表 2 に試作した光 LAN カードの主要性能を示す。製作し た $1 \mathrm{~Gb} / \mathrm{s}$ 光 $\mathrm{LAN}$ カードの寸法は, $159.0 \times 57.0 \times 10.5 \mathrm{~mm}$ である。これはデスクトップ PC 用の市販 NIC とほぼ同じ 寸法である。光 LAN カードの体積と重量は, それぞれ $112 \mathrm{ml}, 99 \mathrm{~g}$ であった。MAC チップや PHY チップのよう な電気系インタフェースに関して, $100 \mathrm{Mb} / \mathrm{s}$ 光 $\mathrm{LAN}$ カード ではノート PC 用に市販された小型薄型の IC を用いること ができたが, $1 \mathrm{~Gb} / \mathrm{s}$ 光 LAN カードではデスクトップ用の大 きな部品を使用せざるをえなかったことも大型化の原因で ある。消費電力も $100 \mathrm{Mb} / \mathrm{s}$ 版より大きく, 光 $\mathrm{LAN}$ カード 全体の消費電力は $3 \mathrm{~W}$ であった。1 $\mathrm{Gb} / \mathrm{s}$ 光 LAN カードにお いても, 電力の大部分は MAC チップや PHY チップによっ て消費された。光 TRX やインタフェース IC が小型化され れば, $1 \mathrm{~Gb} / \mathrm{s}$ 光 LAN カードも Type-II 準拠とすることが可 能であると考えられる。特にこれらの部品は厚さが大きい ため Type-II 規格に収納できず, $1 \mathrm{~Gb} / \mathrm{s}$ 光 LAN カードは Type-II の 2 倍の厚さの Type-III 規格となった。ノート PC 用であって, スループットが $1 \mathrm{~Gb} / \mathrm{s}$ の MAC, PHY チップセ ットと CardBus ドライバ IC が入手可能になれば, ホーム ネットワークにおいても光の低損失, 高速性をいかして $1 \mathrm{~Gb} / \mathrm{s}$ のスループットが実現できると考えられる。スループ ットや伝送距離のメリットに加えて, 電磁環境の観点から も光 LAN カードの工場や病院利用が期待される(5)。

\section{5. 結 論}

小型でかつ一心双方向通信可能な 2 種類の光 LAN カード の研究開発の進展状況およびその応用について報告した。 いずれもノート PC で標準的に装備された PCMCIA 準拠し ており，FTTD を実現するポテンシャルを持つことを確認 した。また, イーサネット側のインタフェースはそれぞれ 100BASE-FX，1000BASE-LX であった。最大スループッ トはそれぞれ約 $95 \mathrm{Mb} / \mathrm{s}$, 約 $200 \mathrm{Mb} / \mathrm{s}$ であることが実験的 に確認された。光 TRX モジュールがカード内で必須である が，媒体の部分でメタルより光ファイバの方が廉価である ことを考慮すれば，光部品によるコスト増も吸収しうるも 
のと考えられる。また FTTH の普及が光部品の低コスト化 を促し，より短距離なネットワークの光化が現実のものに なるであろう。これらの光 LAN カードは近い将来, LAN やのホームネットワークの光化に貢献するであろう。

(平成 18 年 1 月 30 日受付，平成 18 年 6 月 16 日再受付)

\section{文献}

(1) K. Oguchi, N. Sugimoto, Y. Suzuki, and H. Toba : "Optical Eathernet, its relevant technologies and applications", Proc. SCI 2002, Vol.XX, p.25 (2002)

(2) M. Yamamoto, T. Sano, M. Miyai, K. Sato, and E. Maekawa : "The access system for 100Mb/s services", Proc. SCI 2002, Vol.X, p.221 (2002)

(3) R. Nagase, E. Sugita, S. Iwana, K. Kanayama, and Y. Ando : "Miniature optical connector with small zirconia ferrule", IEEE Photon. Technol. Lett., Vol.3, pp.1045-1047 (1991)

(4) T. Hashimoto, T. Kurosaki, M. Yanagisawa, Y. Suzuki, Y. Akahori, Y. Inoue, Y. Tohmori, K. Kato, Y. Yamada, and N. Ishihara : "A 1.3/1.55- $\mu \mathrm{m}$ wavelength-division multiplexing optical module using a planer lightwave circuit for full duplex operation", IEEE J. Lightwave Technol. Vol.18, pp.1541-1547 (2000)

(5) N. Sugimoto, S. Fukushima, Y. Sakai, K. Oguchi, and Y. Akatsu : "A small optical Ethernet PC card for fiber-to-the-noteboook PCs and its applications", Proc. Asia-Pacific Optical Communications (APOC2004), paper 5625-68, Beijing, China (2004-11)

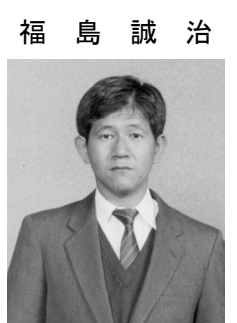

員。工学博士。

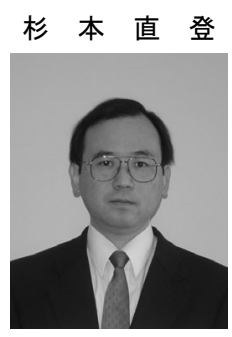

（非会員） 1961 年生。1986 年九州大学大院理 学研究科物理学専攻修士課程修了。1997 年博 士 (工学) 取得。1986 年 4 月日本電信電話株 式会社入社, 以来光通信用材料, デバイス, 機 器の開発に従事。2004 年 NTT エレクトロニク ス株式会社に出向し現在にいたる。 IEEE/LEOS, OSA, 応用物理学会, 日本物理 学会各会員。

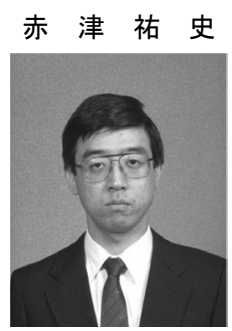

(非会員) 1988 年北海道大学大学院工学研究 科博士課程修了, 同年日本電信電話株式会社入 社, 光エレクトロニクス研究所勤務。現在フォ トニクス研究所主幹研究員。主に光半導体の結 晶成長, 集積光デバイス, 光モジュールの研究 開発に従事。電子情報通信学会, 応用物理学会, IEEE 各会員。

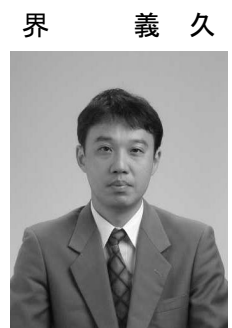

（非会員） 1986 年金沢大学工学部電子工学科 卒業, 1988 年同大学院工学研究科電子工学専 攻修士課程修了, 同年 NTT に入社, 光エレク トロニクス研究所勤務。1995 年工学博士。同 年電子情報通信学会学術奨励賞受賞。現在フォ トニクス研究所主幹研究員。半導体レーザの波 長安定化技術, 光加入者用半導体レーザの研究 開発, 次世代フォトニックネットワークの開発 に従事。著書”Frequency stabilization of semiconductor laser diodes（共著）”(Artech House Publishers, 1995)。

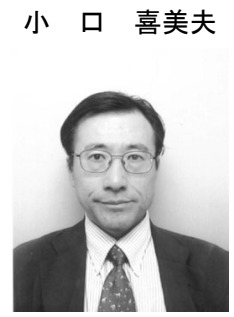

(会員) $\mathrm{BE}, \mathrm{ME}$ ，工学博士を名古屋大学に てそれぞれ 1978，1980，1995 年に取得。1980 年電電公社横須賀電気通信研究所勤務。1980 年から 2004 年まで光 LAN, ATM システム, 先端光デバイスの研究に従事。ITU-T, SG 13 及び 15 にて標準化業務に従事。現在成蹊大学 理工学部教授。OECC'97, NOC'97, OECC'98 でそれぞれ Best Paper Award 受賞。電気学会, 電子情報通信学会, IEEE, OSA 各会員。 